\title{
Apigenin inhibits the proliferation of adenoid cystic carcinoma via suppression of glucose transporter-1
}

\author{
JIN FANG $^{1}$, YANG-YANG BAO ${ }^{2}$, SHUI-HONG ZHOU ${ }^{2}$ and JUN FAN ${ }^{3}$ \\ ${ }^{1}$ Department of Otolaryngology, The Second Hospital of Jiaxing City, Jiaxing, Zhejiang 314000; \\ ${ }^{2}$ Department of Otolaryngology; ${ }^{3}$ State Key Laboratory for Diagnosis and Treatment of Infectious Diseases, \\ The First Affiliated Hospital, College of Medicine, Zhejiang University, Hangzhou, Zhejiang 310003, P.R. China
}

Received March 2, 2014; Accepted July 17, 2015

DOI: $10.3892 / \mathrm{mmr} .2015 .4233$

\begin{abstract}
Apigenin is a natural phyto-oestrogen flavonoid, which exerts various biological effects, including anti-oxidative, anti-inflammatory and anticancer activities. In addition, apigenin has recently been reported to target hypoxic markers; however, there are currently no studies regarding the association between apigenin and glucose transporter-1 (GLUT-1) in adenoid cystic carcinoma (ACC). The present study investigated whether apigenin inhibits the proliferation of ACC cells or suppresses the expression of GLUT-1 in ACC cells. The results of the present study demonstrated that apigenin inhibits ACC- 2 cell growth in a dose- and time-dependent manner. Treatment with apigenin also induced apoptosis and $\mathrm{G}_{2} / \mathrm{M}$-phase arrest in a dose- and time-dependent manner. Corresponding with the above results, the expression levels of GLUT-1 were significantly decreased following treatment in a dose- and time-dependent manner. These results suggest that the inhibition of ACC-2 cell growth by apigenin may be due to the decreased expression of GLUT-1.
\end{abstract}

\section{Introduction}

Adenoid cystic carcinoma (ACC) is characterised by a prolonged clinical course, frequent local recurrence and perineural invasion (1-3). The standard primary treatment strategies for local and locoregional disease are surgery and/or irradiation (3); however, the long-term outcomes of these treatments are unfavourable. Various drugs have been used in the field of targeted therapy against ACC; however, the predominant effect of these drugs is disease stabilisation. Therefore, novel strategies are required to improve kill ACC cells with

Correspondence to: Professor Shui-Hong Zhou, Department of Otolaryngology, The First Affiliated Hospital, College of Medicine, Zhejiang University, 79 Qingchun Road, Hangzhou, Zhejiang 310003, P.R. China

E-mail: zhouyunzhoush@163.com

Key words: apigenin, head and neck, adenoid cystic carcinoma, glucose transporter-1, anticancer effect lower systemic toxicity, particularly for use in combination therapy.

Apigenin is a natural phyto-oestrogen flavonoid, which exerts various biological effects, including anti-oxidative, anti-inflammatory and anticancer activities (4). Apigenin has been shown to inhibit prostate (5), thyroid (6), breast (7), pancreatic (8), ovarian (9), and head and neck cancer (10), via the selective inhibition of tumour cell proliferation. Numerous studies have investigated the effects of apigenin; however, the underlying biomolecular mechanism remains to be elucidated.

Apigenin has recently been reported to target the hypoxic markers hypoxia-inducible factor- $1 \alpha(\mathrm{HIF}-1 \alpha)$, glucose transporter-1 (GLUT-1), and vascular endothelial growth factor in human pancreatic $(8,11)$, ovarian $(12)$, and lung carcinoma cell lines (13). Similar to other malignant tumours, ACC cells exhibit increased glucose uptake and utilisation, as compared with their non-malignant counterparts, and GLUT-1 is considered to have a key molecular regulatory role in this process. In addition, GLUT-1 is correlated with the aggressive biological behaviour of other types of human cancer $(14,15)$. Our previous study indicated that the radioresistance of laryngeal carcinoma may be associated with increased expression of GLUT-1 mRNA and protein (16). In addition, GLUT-1 antisense oligodeoxynucleotides were able to enhance the radiosensitivity of laryngeal carcinoma, predominantly via inhibition of GLUT-1 expression (16). Therefore, GLUT-1 is regarded as a potential therapeutic target in certain types of cancer $(17,18)$. To the best of our knowledge, there are currently no studies regarding the association between apigenin and GLUT-1 in ACC.

The present study aimed to investigate whether apigenin inhibits the proliferation of ACC cells, and whether it may suppress the expression of GLUT-1 in ACC cells.

\section{Materials and methods}

Cell culture. The ACC-2 human adenoid cystic carcinoma cell line was purchased from the Cell Research Institute of the Chinese Academy of Sciences (Shanghai, China). The ACC-2 cells were cultured in Dulbecco's modified Eagle's medium (DMEM; Gibco Life Technologies, Grand Island, NY, USA) supplemented with $10 \%$ heat-inactivated foetal bovine serum (Hyclone, GE Healthcare, Logan, UT, USA), 
$2 \mathrm{mM}$ L-glutamine, $100 \mathrm{U} / \mathrm{ml}$ penicillin, and $100 \mathrm{~g} / \mathrm{ml}$ streptomycin (100biotech Co., Ltd., Hangzhou, China) at $37^{\circ} \mathrm{C}$ in an atmosphere containing $5 \% \mathrm{CO}_{2}$. The cells were trypsinised and harvested after reaching $80-90 \%$ confluence.

Proliferation assay of ACC-2 cells using the Cell Counting kit-8 (CCK-8) system. Cultured ACC-2 cells were trypsinised with $0.25 \%$ trypsin (100biotech Co., Ltd). Cell proliferation was measured using the CCK-8 system (Beyotime Institute of Biotechnology, Nanjing, China), according to the manufacturer's instructions. Briefly, $3 \times 10^{3}$ ACC-2 cells were seeded into 96-well culture plates and treated with either DMEM, or 10,40 or $160 \mu \mathrm{M}$ apigenin (Selleckchem, Houston, TX, USA) The cells were cultured in serum-free medium (100biotech Co., Ltd.) at $37^{\circ} \mathrm{C}$ for $1,2,3,4$ or 5 days. A total of $10 \mu \mathrm{l} \mathrm{CCK-8}$ reagent was added to each well, and incubated at $37^{\circ} \mathrm{C}$ for $3 \mathrm{~h}$, and the absorbance was measured at $450 \mathrm{~nm}$. Optical density (OD) was calculated as follows: $\mathrm{OD}=\mathrm{OD}_{\text {cell }}$ - $\mathrm{OD}_{\text {blank }}$.

Cell cycle analysis using flow cytometry. A total of $3 \times 10^{3}$ ACC- 2 cells were seeded into 96-well culture plates and treated with either DMEM, or 10, 40 or $160 \mu \mathrm{M}$ apigenin for 24,48 or $72 \mathrm{~h}$. The cells from each group were trypsinised with $0.25 \%$ trypsin and rinsed in phosphate-buffered saline (PBS). The cells were centrifuged at $800 \mathrm{xg}$ for $5 \mathrm{~min}$ and resuspended in up to $500 \mu 1$ PBS. The cells were centrifuged at 2,000 x g for $5 \mathrm{~min}$, collected and fixed in ice-cold $70 \%$ ethanol for $24 \mathrm{~h}$, prior to re-centrifugation. The cells were then incubated with RNase $(0.5 \mathrm{mg} / \mathrm{ml})$ and stained with $1 \mathrm{ml}$ of $50 \mu \mathrm{g} / \mathrm{ml}$ propidium iodide (PI; Sigma-Aldrich, St. Louis, MO, USA) in the dark for $30 \mathrm{~min}$ at room temperature. The cells were subsequently added to $5 \mu \mathrm{l}$ Annexin V-fluorescein isothiocyanate (FITC) and $5 \mu \mathrm{PI}$, and incubated for a further $15 \mathrm{~min}$ at $25^{\circ} \mathrm{C}$. The cells were then added to $400 \mu \mathrm{l}$ binding buffer in the dark for $1 \mathrm{~h}$. The FACScan analysis system (BD Biosciences, Franklin Lakes, NJ, USA) was then used to collect flow cytometry (FCM) data to determine changes in cell cycle distribution. Each experiment was performed three times in triplicate.

Cell apoptosis analysis using flow cytometry. A total of $3 \times 10^{3}$ ACC-2 cells were seeded into 96-well culture plates and treated with either DMEM or 10,40 , or $160 \mu \mathrm{M}$ apigenin for 24,48 or $72 \mathrm{~h}$. The cells from each group were trypsinised using $0.25 \%$ trypsin and rinsed in PBS. The cells were centrifuged at $800 \mathrm{x} \mathrm{g}$ for $5 \mathrm{~min}$ and resuspended in up to $500 \mu \mathrm{l}$ PBS. The cells was centrifuged at $2,000 \times \mathrm{g}$ for $5 \mathrm{~min}$, collected and fixed in ice-cold $70 \%$ ethanol for $24 \mathrm{~h}$ and re-centrifuged. The cells were then incubated with $500 \mu 1$ binding buffer in the dark for $30 \mathrm{~min}$ at room temperature. The cells were added to $5 \mu \mathrm{l}$ Annexin V-FITC and $5 \mu 1 \mathrm{PI}$, followed by incubation for $15 \mathrm{~min}$ at $25^{\circ} \mathrm{C}$. The FACScan analysis system was then used to collect FCM data on changes in cell apoptosis. Each experiment was performed three times in triplicate.

Determination of GLUT-1 mRNA expression in ACC-2 cells by reverse transcription-quantitative polymerase chain reaction $(R T-q P C R)$. Briefly, $3 \times 10^{3}$ ACC- 2 cells were seeded into 96-well culture plates and treated with either DMEM, or 10,40 or $160 \mu \mathrm{M}$ apigenin for 24,48 , or $72 \mathrm{~h}$.
The ACC-2 cells were homogenised in TRIzol ${ }^{\circledR}$ reagent (Invitrogen Life Technologies, Carlsbad, CA, USA) and total RNA was extracted, according to the manufacturer's instructions. A total of $1 \mu \mathrm{g}$ RNA was added to M-MLV reverse transcriptase (100biotech Co., Ltd.) in a $20 \mu 1$ reaction volume, and the reaction mix was pre-denatured at $65^{\circ} \mathrm{C}$ for $10 \mathrm{~min}$. After the addition of $200 \mathrm{U}$ M-MLV, the samples were incubated at $42^{\circ} \mathrm{C}$ for $1 \mathrm{~h}$ and annealed at $70^{\circ} \mathrm{C}$ for $10 \mathrm{~min}$. The newly synthesised cDNA was used as a template for RT-qPCR. The $20 \mu 1$ PCR reaction mix consisted of $10 \mu 12 X$ SYBR Green (Toboyo Co., Ltd., Tokyo, Japan), $1 \mu \mathrm{l}$ cDNA template, $1 \mu 1$ upstream and downstream specific primers, and $8 \mu 1$ deionised water. The PCR cycling conditions were as follows: Pre-denaturation at $95^{\circ} \mathrm{C}$ for $2 \mathrm{~min}$, followed by 40 cycles at $95^{\circ} \mathrm{C}$ for $15 \mathrm{sec}, 59^{\circ} \mathrm{C}$ for $20 \mathrm{sec}$ and $72^{\circ} \mathrm{C}$ for $20 \mathrm{sec}$ and a final extension step at $72^{\circ} \mathrm{C}$ for $10 \mathrm{~min}$. Experiments were performed in triplicate and were repeated at least twice independently. The primers used were as follows: Forward: 5'-CCGCAACGAGGAGAACCG-3' and reverse: 5'-GTGACCTTCTTCTCCCGCATC-3' for GLUT-1; and forward: 5'-TGTTGCCATCAATGACCCCTT-3', and reverse: 5'-CTCCACGACGTACTCAGCG-3' fir GAPDH. GAPDH was used as an internal standard for data calibration. The lengths of the PCR products were 123 bp (GLUT-1) and 202 bp (GAPDH). Dissociation curve analysis was conducted, and the $2^{-\Delta \Delta \mathrm{Ct}}$ quantification method was used to calculate differential gene expression.

Determination of GLUT-1 protein levels in ACC-2 cells by western blotting. The GLUT-1 and $\beta$-actin (control) protein expression levels were detected in each group of ACC-2 cells by western blotting. Following extraction of the GLUT-1 and $\beta$-actin proteins, the protein concentration was determined using a bicinchoninic acid protein quantitative kit (Wuhan Boster Biological Technology Co. Ltd., Wuhan, China). Briefly, $80 \mu \mathrm{g}$ protein was separated by $10 \%$ SDS-PAGE and transferred onto a nitrocellulose membrane (EMD Millipore, Billerica, MA, USA). Skimmed milk (2\%) was used to block the membrane at room temperature for $1 \mathrm{~h}$. The membrane was then incubated with the following primary antibodies: Rabbit anti-human polyclonal GLUT-1 (1:1,000; cat. no. ab14683; Abcam, Cambridge, UK) and mouse anti-human monoclonal $\beta$-actin (1:5,000; Abcam) at room temperature for $3 \mathrm{~h}$, followed by an incubation with donkey anti-rabbit $(1: 5,000)$ and donkey anti-mouse $(1: 2,000)$ secondary antibodies at room temperature for $1 \mathrm{~h}$. The blots were visualized using an enhanced chemiluminescence system (Santa Cruz Biotechnology, Inc., Dallas, TX, USA) and were exposed to X-ray film. Protein expression was semi-quantitatively analysed using the Kodak Gel Logic Analysis system (Kodak, Rochester, NY, USA).

Statistical analysis. Statistical analyses were performed using SPSS for Windows, version 19.0 (IBM SPSS, Armonk, NY, USA). An independent t-test was used for analysis. $\mathrm{P}<0.05$ was deemed to indicate a statistically significant difference.

\section{Results}

Apigenin inhibits the growth of ACC-2 cells. The CCK-8 assay demonstrated that various concentrations (10-160 $\mu \mathrm{M})$ 


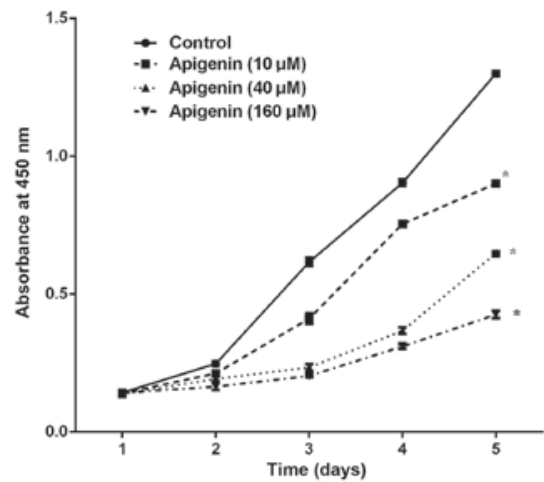

Figure 1. Various concentrations (10-160 $\mu \mathrm{M})$ and durations (1-5 days) of apigenin treatment resulted in a dose- and time-dependent inhibition of ACC-2 human adenoid cystic carcinoma cell growth, as determined by Cell Counting kit- 8 . ${ }^{*} \mathrm{P}<0.05$ vs. control on days $2-5$.

A

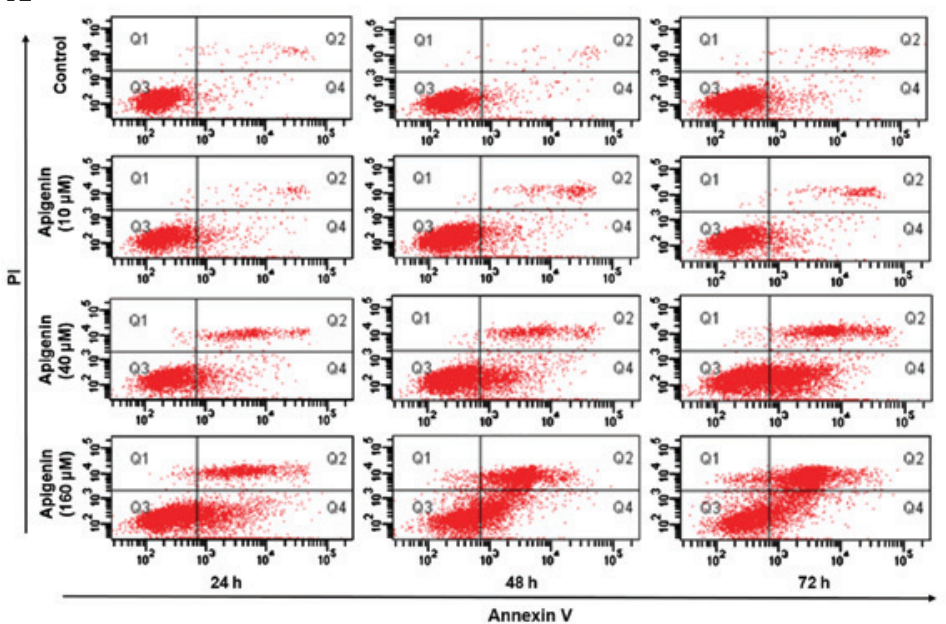

B

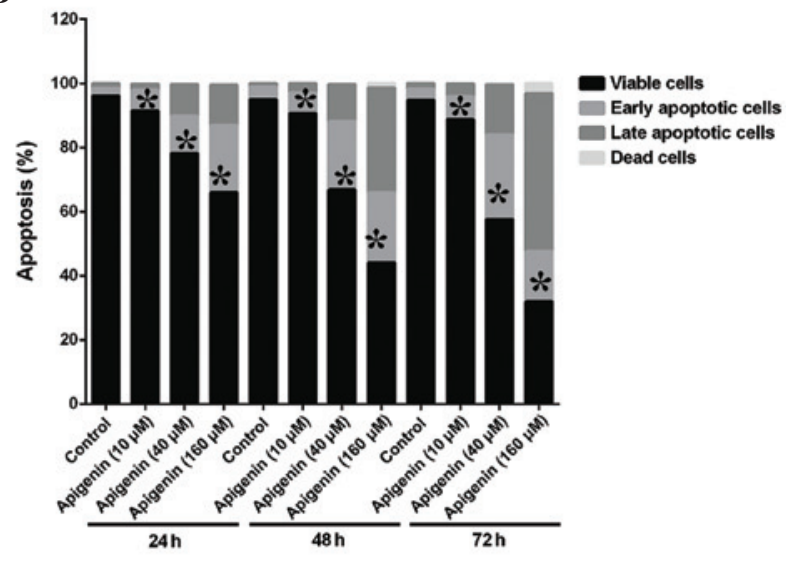

Figure 2. (A) Flow cytometry was used to determine the rate of apoptosis of ACC-2 human adenoid cystic carcinoma cells following treatment with apigenin. (B) Treatment with apigenin induced apoptosis in a dose- and time-dependent manner, as compared with the control. "P<0.05 vs. control. FITC, fluorescein isothiocyanate; PI, propidium iodide.
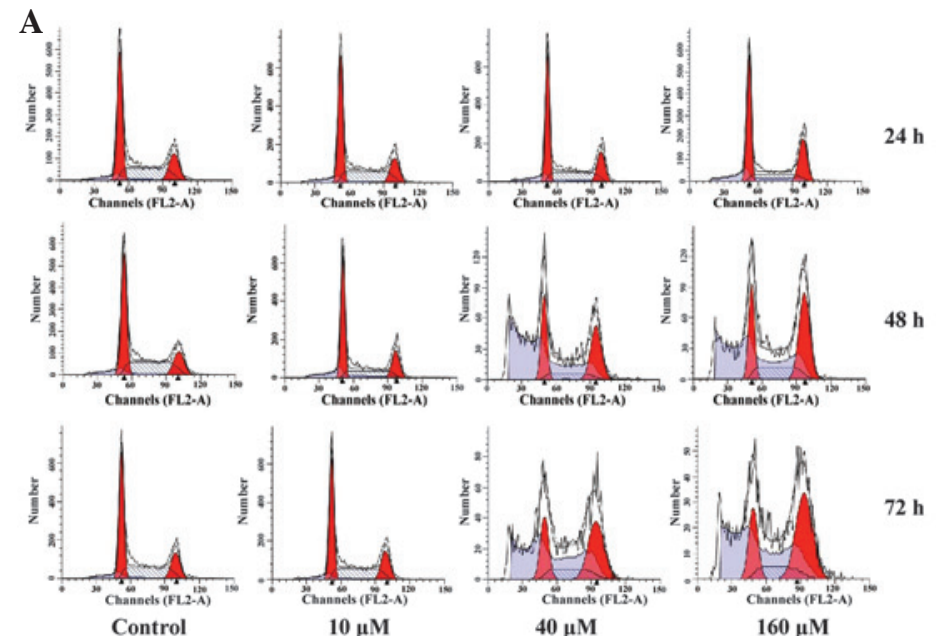

B

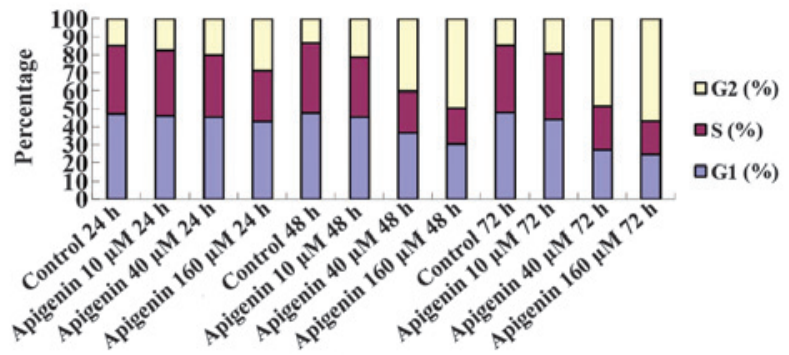

Figure 3. (A) Flow cytometry was used to determine cell cycle distribution of ACC-2 human adenoid cystic carcinoma cells following treatment with apigenin. (B) The $\mathrm{G}_{2} / \mathrm{M}$-phase population of the control cells was $14.65 \%$, which was markedly increased after 24,48 and $72 \mathrm{~h}$ of treatment with various doses of apigenin.

and durations (1-5 days) of apigenin treatment resulted in a dose- and time-dependent inhibition of ACC-2 cell growth, as compared with the control $(\mathrm{P}<0.05$; Fig. 1$)$.
Apigenin induces apoptosis and cell cycle arrest in ACC-2 cells. The ACC-2 cells were treated with various concentrations $(10-160 \mu \mathrm{M})$ of apigenin for 24,48 , and $72 \mathrm{~h}$ and 
Table I. Distribution of ACC-2 cells in the cell cycle exposed to different concentration of apigenin over time.

\begin{tabular}{lccc}
\hline Group & G1 $(\%)$ & S (\%) & G2 (\%) \\
\hline $24 \mathrm{~h}$ & & & \\
Control & 47.42 & 37.93 & 14.65 \\
$10 \mu \mathrm{M}$ apigenin & 46.13 & 36.49 & 17.38 \\
$40 \mu \mathrm{M}$ apigenin & 45.42 & 34.54 & 20.04 \\
$160 \mu \mathrm{M}$ apigenin & 43.26 & 27.89 & 28.85 \\
$48 \mathrm{~h}$ & & & \\
Control & 47.89 & 38.74 & 13.37 \\
$10 \mu \mathrm{M}$ apigenin & 45.51 & 33.4 & 21.09 \\
$40 \mu \mathrm{M}$ apigenin & 36.81 & 22.91 & 40.28 \\
$160 \mu \mathrm{M}$ apigenin & 30.46 & 20.08 & 49.46 \\
$72 \mathrm{~h}$ & & & \\
Control & 48.05 & 37.46 & 14.49 \\
$10 \mu \mathrm{M}$ apigenin & 44.41 & 36.43 & 19.16 \\
$40 \mu \mathrm{M}$ apigenin & 27.32 & 24.41 & 48.27 \\
$160 \mu \mathrm{M}$ apigenin & 24.64 & 18.75 & 56.61 \\
\hline
\end{tabular}

apoptotic cell death and cell cycle alterations were detected using FCM (Fig. 2A). Treatment with apigenin induced apoptosis in a dose- and time-dependent manner, as compared with the control (Fig. 2B). The percentage of apoptotic cells increased to $64.8 \%$ following treatment with $160 \mu \mathrm{M}$ apigenin. In addition, the results of the FCM demonstrated that the cell cycle progressed from $G_{1}$ to $G_{2}$ phase, and was arrested at $\mathrm{G}_{2} / \mathrm{M}$ phase in a dose- and time-dependent manner (Fig. 3A). The $\mathrm{G}_{2} / \mathrm{M}$-phase population of the control cells was $14.65 \%$, and was markedly increased after 24,48 and $72 \mathrm{~h}$ of treatment with various concentrations of apigenin (Table I, Fig. 3B).

Apigenin downregulates the $m R N A$ and protein expression levels of GLUT-1 in ACC-2 cells. To determine the GLUT-1 mRNA and protein expression levels in ACC-2 cells, RT-qPCR and western blotting were conducted, respectively. GLUT-1 mRNA expression levels were significantly reduced following treatment with increasing doses of apigenin $(\mathrm{P}<0.05$; Table II, Fig. 4). Following treatment with $10 \mu \mathrm{M}$ apigenin, the mRNA expression levels of GLUT-1 did not vary significantly with increasing treatment duration $(\mathrm{P}>0.05)$. Conversely, following treatment with 40 and $160 \mu \mathrm{M}$ apigenin, the expression levels of GLUT-1 mRNA were significantly reduced with increasing treatment duration ( $\mathrm{P}<0.05$; Table II, Fig. 4). Western blotting demonstrated that the GLUT-1 protein expression levels were reduced following apigenin treatment in a dose- and time-dependent manner (Fig. 5A and B).

\section{Discussion}

At present, patients with ACC receive comprehensive treatment, including extensive local resection; medical neck dissection when cervical lymph node metastases are present; and treatment combined with postoperative radiotherapy
Table II. mRNA expression levels of GLUT- 1 in ACC-2 cells treated with different concentrations of apigenin over time.

\begin{tabular}{lccc}
\hline & \multicolumn{3}{c}{ GLUT-1 mRNA } \\
\cline { 2 - 4 } Group & $24 \mathrm{~h}$ & $48 \mathrm{~h}$ & $72 \mathrm{~h}$ \\
\hline Control & $1.00 \pm 0.11$ & $1.00 \pm 0.20$ & $1.00 \pm 0.07$ \\
Apigenin & & & \\
$10 \mu \mathrm{M}$ & $0.72 \pm 0.08$ & $0.69 \pm 0.09$ & $0.60 \pm 0.06$ \\
$40 \mu \mathrm{M}$ & $0.48 \pm 0.09$ & $0.40 \pm 0.04$ & $0.25 \pm 0.02$ \\
$160 \mu \mathrm{M}$ & $0.28 \pm 0.05$ & $0.22 \pm 0.02$ & $0.13 \pm 0.01$ \\
\hline
\end{tabular}

Expression values are expressed relative to GAPDH.

and/or chemotherapy in cases of advanced ACC; however, the results are usually unfavourable. In addition, patients with ACC are usually insensitive to chemo-radiotherapy, which results in high recurrence rates and distant metastasis at an early stage (3). Therefore, identification of novel molecular targets is of great importance.

Apigenin has previously been reported to exert its anticancer effect via various mechanisms (5-11). It has been reported that apigenin may suppress human cancer by inhibiting the expression of GLUT-1 $(8,11)$. To the best of our knowledge, there are currently no studies regarding the interaction between apigenin and GLUT-1 in ACC. The results of the present study demonstrated that apigenin inhibits the proliferation of ACC-2 cells in a dose-and time-dependent manner, this finding is concordant with the results of previous studies regarding other types of cancer $(13,19,20)$. In other cell lines, apigenin has also been shown to induce apoptosis and cell cycle arrest $(13,19,20)$. In T24 bladder cancer cells, Zhu et al (21) demonstrated that treatment with apigenin resulted in increases in apoptosis and $\mathrm{G}_{2} / \mathrm{M}$-phase arrest, with an almost 2.6-fold increase, in a dose-dependent manner. In a lung adenocarcinoma cell line, Bruno et al (19) demonstrated that apigenin significantly decreased cell proliferation and augmented cell death and apoptosis. In addition, apigenin has been shown to inhibit growth, induce apoptosis, and promote $\mathrm{G}_{2} / \mathrm{M}$ phase cell cycle arrest in head and neck squamous cell carcinoma cells (10). In the present study, apigenin induced ACC- 2 cell apoptosis, and $\mathrm{G}_{2} / \mathrm{M}$-phase arrest. The percentage of apoptotic cells increased to $64.8 \%$ following treatment with $160 \mu \mathrm{M}$ apigenin, and the percentage of cells in $\mathrm{G}_{2} / \mathrm{M}$ phase dose-dependently increased from 17.38 to $28.85 \%$ after $24 \mathrm{~h}$, from 21.09 to $49.46 \%$ after $48 \mathrm{~h}$, and from 19.16 to $56.61 \%$, an almost 2.7 -fold increase, after $72 \mathrm{~h}$. In addition, the percentage of cells in the $\mathrm{G}_{2} / \mathrm{M}$ phase increased in a time-dependent manner from 17.38 to $56.61 \%$, an almost 3.3-fold increase. The results of the present study, as well as those of previous studies, suggested that apigenin-induced cell growth inhibition may be due to cell cycle arrest (21). In addition, apigenin has been shown to cause $\mathrm{G}_{0} / \mathrm{G}_{1}$-phase arrest, resulting in death and apoptosis of human prostate cancer cells (20) and cervical carcinoma cells (22). These results suggested that apigenin-induced cell cycle arrest may be caused by various molecular regulatory mechanisms, and the distinct characteristics of cancer cell lines. 

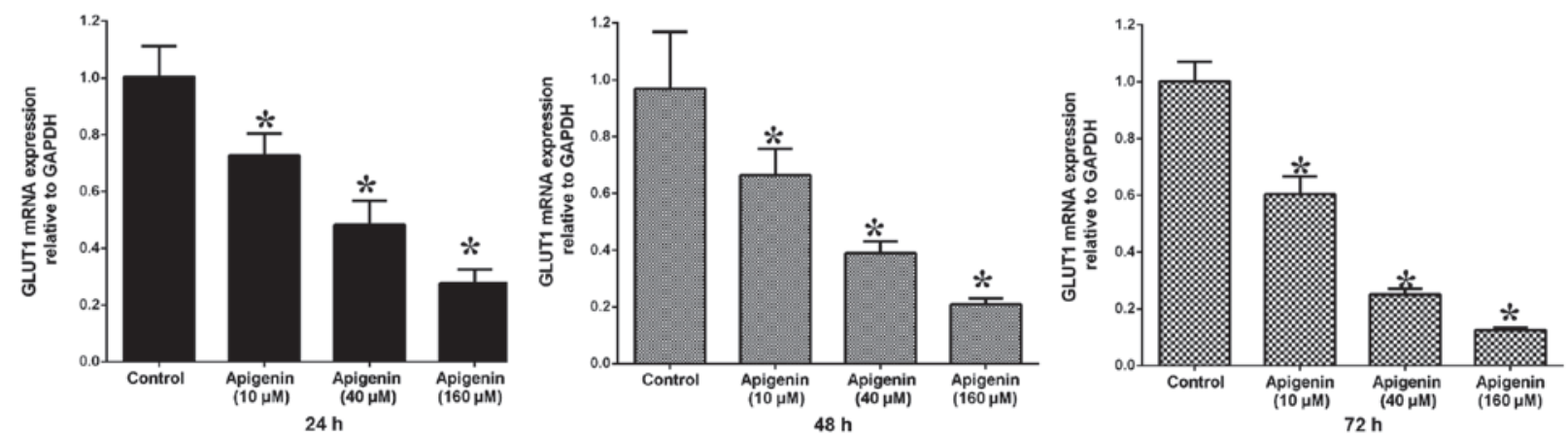

Figure 4. GLUT-1 mRNA expression levels were significantly reduced in the ACC-2 human adenoid cystic carcinoma cells following treatment with increasing doses of apigenin $(\mathrm{P}<0.05)$, as determined by reverse transcription-quantitative polymerase chain reaction. Following treatment with $10 \mu \mathrm{M}$ apigenin, the expression levels of GLUT-1 mRNA did not vary significantly with increasing treatment duration ( $\mathrm{P}>0.05)$. Following treatment with 40 and $160 \mu \mathrm{M}$ apigenin, the expression levels of GLUT-1 mRNA were significantly reduced with increasing treatment duration. ${ }^{*} \mathrm{P}<0.05$ vs. control. GLUT-1, glucose transporter-1.

A

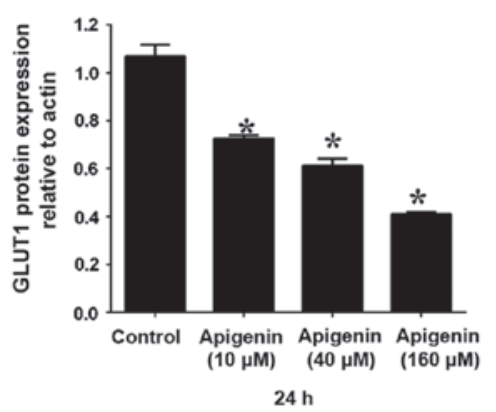

B

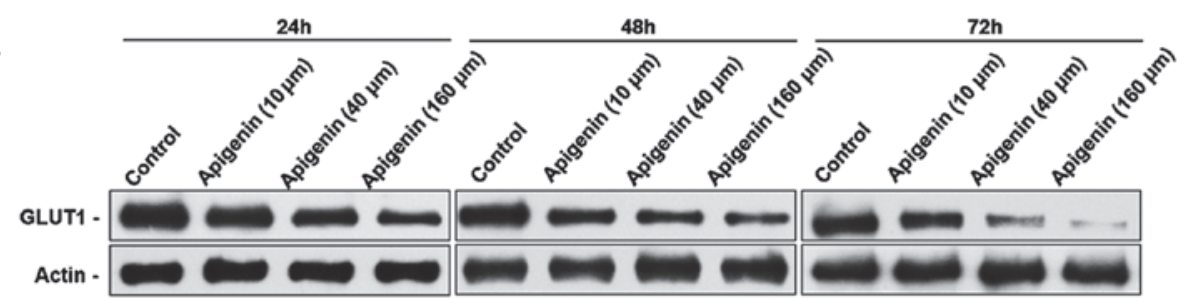

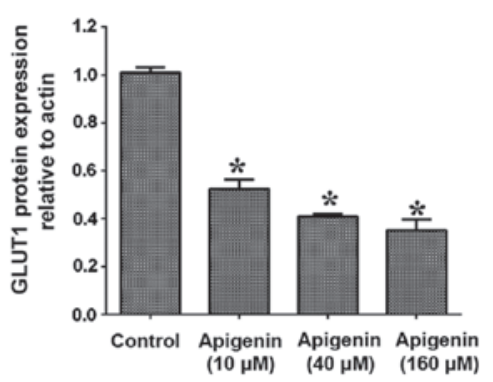

$(10 \mu \mathrm{M}) \quad \underset{(40 \mu \mathrm{M})}{(160 \mu \mathrm{M})}$ $48 \mathrm{~h}$

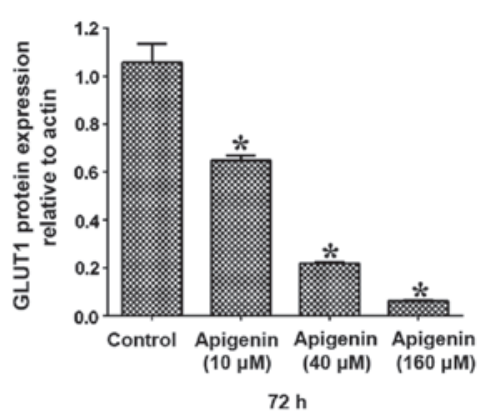

$72 \mathrm{~h}$

genin. (B) Relative protein expression levels of GLUT-1 were reduced in a dose- and time-dependent manner. ${ }^{*}$ P $<0.05$ vs. control. GLUT-1, glucose transporter-1.

The anticancer mechanism of apigenin remains unclear (23). Apigenin has recently been reported to target hypoxic markers, and GLUT-1 is an intrinsic marker of malignant tumour hypoxia (24). GLUT-1 overexpression enables the transport of increased levels of glucose to fulfil the high metabolic rate and rapid growth requirements of malignant cells. In our previous study, it was demonstrated that overexpression of GLUT-1 may have a role in the development of recurrence of ACC-2 cells (2). In addition, GLUT-1 has been suggested as a potential therapeutic target in other types of cancer $(14,15)$. In certain human cancer cell lines, apigenin has been shown to decrease the expression of GLUT-1, and exert an anticancer effect (5-12). The present study demonstrated that apigenin-induced cell apoptosis may be due to decreased expression of GLUT-1 in ACC-2 cells. Corresponding with the inhibition of proliferation of ACC-2 cells and increased cell apoptosis, the expression levels of GLUT-1 were significantly decreased following treatment with apigenin in a dose- and time-dependent manner. The relative mRNA expression levels of GLUT-1 were decreased by $\sim 5.5$-fold from 0.72 to 0.13 , and the relative protein expression levels of GLUT-1 decreased by $\sim 14.6$-fold from 0.73 to 0.05 . The mechanism underlying these changes may involve inhibition of glucose absorption by ACC- 2 cells. In human pancreatic cancer cells, Melstrom et al (8) demonstrated that $100 \mu \mathrm{M}$ apigenin inhibited cell growth and lowered GLUT-1 mRNA expression. The same study also reported that apigenin was able to inhibit GLUT-1 expression at the transcriptional and translational levels in a dose- and time-dependent manner in human pancreatic cancer. However, the mechanism by which apigenin inhibits GLUT-1 expression is currently unknown. Melstrom et al (8) reported that apigenin may inhibit the phosphoinositide 3-kinase (PI3K)/Akt pathway in order to reduce GLUT-1 expression, thus inhibiting the absorption of glucose by pancreatic cancer cells, resulting in apoptosis. However, it was also detected that overexpression of phosphorylated-Akt did not completely attenuate the effects of apigenin on GLUT-1, indicating that the PI3K/Akt pathway is not solely responsible for the downregulation of GLUT-1 in pancreatic cancer cells treated with apigenin (8). Therefore, the mechanism by which apigenin inhibits GLUT-1 expression requires further investigation. Our future studies aim to 
investigate whether apigenin inhibits GLUT-1 expression via the PI3K/Akt-HIF axis in ACC.

In conclusion, the present study demonstrated that apigenin inhibits proliferation and induces cell apoptosis, and $\mathrm{G}_{2} / \mathrm{M}$-phase arrest in ACC-2 cells, possibly due to decreased GLUT-1 expression.

\section{Acknowledgements}

The present study was supported by the Health Department of Zhejiang Province, China (grant no. 2012KYB206), and the National Natural Science Foundation of China (grants nos. 81172562 and 81372903).

\section{References}

1. Kim B: Palliative radiotherapy in a patient with pulmonary adenoid cystic carcinoma. Cancer Res Treat 39: 185-188, 2007.

2. Fang J, Bao YY, Zhou SH, Luo XM, Yao HT, He JF and Wang QY: Recurrent prognostic factors and expression of GLUT-1, PI3K and p-Akt in adenoid cystic carcinomas of the head and neck: Clinicopathological features and biomarkers of adenoid cystic carcinoma. Oncol Lett 4: 1234-1240, 2012.

3. Papaspyrou G, Hoch S, Rinaldo A, Rodrigo JP, Takes RP, van Herpen C, Werner JA and Ferlito A: Chemotherapy and targeted therapy in adenoid cystic carcinoma of the head and neck: A review. Head Neck 33: 905-911, 2011.

4. Patel D, Shukla S and Gupta S: Apigenin and cancer chemoprevention: Progress, potential and promise (review). Int J Oncol 30: 233-245, 2007.

5. Oishi M, Iizumi Y, Taniguchi T, Goi W, Miki T and Sakai T: Apigenin sensitizes prostate cancer cells to Apo2L/TRAIL by targeting adenine nucleotide translocase-2. PLoS One 8: e55922, 2013.

6. Kim SH, Kang JG, Kim CS, Ihm SH, Choi MG, Yoo HJ and Lee SJ: Apigenin induces c-Myc-mediated apoptosis in FRO anaplastic thyroid carcinoma cells. Mol Cell Endocrinol 369: 130-139, 2013.

7. Cao X, Liu B, Cao W, Zhang W, Zhang F, Zhao H, Meng R, Zhang L, Niu R, Hao X and Zhang B: Autophagy inhibition enhances apigenin-induced apoptosis in human breast cancer cells. Chin J Cancer Res 25: 212-222, 2013.

8. Melstrom LG, Salabat MR, Ding XZ, Milam BM, Strouch M, Pelling JC and Bentrem DJ: Apigenin inhibits the GLUT-1 glucose transporter and the phosphoinositide 3-kinase/Akt pathway in human pancreatic cancer cells. Pancreas 37: 426-431, 2008.

9. He J, Xu Q, Wang M, Li C, Qian X, Shi Z, Liu LZ and Jiang BH: Oral administration of apigenin inhibits metastasis through AKT/P70S6K1/MMP-9 pathway in orthotopic ovarian tumor model. Int J Mol Sci 13: 7271-7282, 2012.
10. Chan LP, Chou TH, Ding HY, Chen PR, Chiang FY, Kuo PL and Liang CH: Apigenin induces apoptosis via tumor necrosis factor receptor- and Bcl-2-mediated pathway and enhances susceptibility of head and neck squamous cell carcinoma to 5-fluorouracil and cisplatin. Biochim Biophys Acta 1820: 1081-1091, 2012.

11. Melstrom LG, Salabat MR, Ding XZ, Strouch MJ, Grippo PJ, Mirzoeva S, Pelling JC and Bentrem DJ: Apigenin down-regulates the hypoxia response genes: HIF-1 $\alpha$, GLUT-1, and VEGF in human pancreatic cancer cells. J Surg Res 167: 173-181, 2011.

12. Fang J, Zhou Q, Liu LZ, Xia C, Hu X, Shi X and Jiang BH: Apigenin inhibits tumor angiogenesis through decreasing HIF-1alpha and VEGF expression. Carcinogenesis 28: 858-864, 2007.

13. Liu LZ, Fang J, Zhou Q, Hu X, Shi X and Jiang BH: Apigenin inhibits expression of vascular endothelial growth factor and angiogenesis in human lung cancer cells: Implication of chemoprevention of lung cancer. Mol Pharmacol 68: 635-643, 2005.

14. Li LF, Zhou SH, Zhao K, Wang SQ, Wu QL, Fan J, Cheng KJ and Ling L: Clinical significance of FDG single-photon emission computed tomography: Computed tomography in the diagnosis of head and neck cancers and study of its mechanism. Cancer Biother Radiopharm 23: 701-714, 2008.

15. Wu XH, Chen SP, Mao JY, Ji XX, Yao HT and Zhou SH: Expression and significance of hypoxia-inducible factor-1a and glucose transporter-1 in laryngeal carcinoma. Oncol Lett 5: 261-266, 2013.

16. Yan SX, Luo XM, Zhou SH, Bao YY, Fan J, Lu ZJ, Liao XB, Huang YP, Wu TT and Wang QY: Effect of antisense oligodeoxynucleotides glucose transporter-1 on enhancement of radiosensitivity of laryngeal carcinoma. Int J Med Sci 10: 1375-1386, 2013.

17. Xu YY, Bao YY, Zhou SH and Fan J: Effect on the expression of MMP-2, MT-MMP in laryngeal carcinoma Hep-2 cell line by antisense glucose transporter-1. Arch Med Res 43: 395-401, 2012.

18. Liu TQ, Fan J, Zhou L and Zheng SS: Effects of suppressing glucose transporter-1 by an antisense oligodeoxynucleotide on the growth of human hepatocellular carcinoma cells. Hepatobiliary Pancreat Dis Int 10: 72-77, 2011.

19. Bruno A, Siena L, Gerbino S, Ferraro M, Chanez P, Giammanco M, Gjomarkaj M and Pace E: Apigenin affects leptin/leptin receptor pathway and induces cell apoptosis in lung adenocarcinoma cell line. Eur J Cancer 47: 2042-2051, 2011.

20. Shukla S and Gupta S: Apigenin-induced cell cycle arrest is mediated by modulation of MAPK, PI3K-Akt, and loss of cyclin D1 associated retinoblastoma dephosphorylation in human prostate cancer cells. Cell Cycle 6: 1102-1114, 2007.

21. Zhu Y, Mao Y, Chen H, Lin Y, Hu Z, Wu J, Xu X, Xu X, Qin J and Xie L: Apigenin promotes apoptosis, inhibits invasion and induces cell cycle arrest of T24 human bladder cancer cells. Cancer Cell Int 13: 54, 2013.

22. Zheng PW, Chiang LC and Lin CC: Apigenin induced apoptosis through p53-dependent pathway in human cervical carcinoma cells. Life Sci 76: 1367-1379, 2005.

23. Bao YY, Zhou SH, Fan J and Wang QY: Anticancer mechanism of apigenin and the implications of GLUT-1 expression in head and neck cancers. Future Oncol 9: 1353-1364, 2013.

24. Kim JI, Choi KU, Lee IS, Choi YJ, Kim WT, Shin DH, Kim K, Lee JH, Kim JY and Sol MY. Expression of hypoxic markers and their prognostic significance in soft tissue sarcoma. Oncol Lett 9: 1699-1706, 2015. 